\title{
The Noncalcemic Analogue of Vitamin D, 22-Oxacalcitriol, Suppresses Parathyroid Hormone Synthesis and Secretion
}

\author{
Alex J. Brown, Cindy R. Ritter, Jane L. Finch, Jeremiah Morrissey, Kevin J. Martin, Eigoro Murayama,* \\ Yasuho Nishii," and Eduardo Slatopolsky \\ The Renal Division, Department of Medicine, Washington University School of Medicine, St. Louis, Missouri 63110; \\ and ${ }^{*}$ Chugai Pharmaceutical Company, Limited, Tokyo, Japan
}

\begin{abstract}
1,25-Dihydroxyvitamin $\mathrm{D}\left(1,25-(\mathrm{OH})_{2} \mathrm{D}_{3}\right)$ directly suppresses the secretion and synthesis of PTH in vivo and in cell culture. This compound has been used to treat secondary hyperparathyroidism associated with renal failure, but in some patients prolonged treatment with $1,25-(\mathrm{OH})_{2} \mathrm{D}_{3}$ results in hypercalcemia. An analogue of $1,25-(\mathrm{OH})_{2} \mathrm{D}_{3}$ with little or no calcemic activity, 22-oxacalcitriol (OCT), was recently developed. We confirmed this lack of calcemic activity by acute and chronic administration to normal rats. A single intraperitoneal injection of vehicle (propylene glycol), OCT, or 1,25-(OH) $)_{2} \mathrm{D}_{3}(1.0$ $\mu \mathrm{g} / \mathrm{rat}$ ) increased calcium by $0.32,0.30$, and $1.40 \mathrm{mg} / \mathrm{dl}$, respectively. When rats were given daily injections of vehicle or $0.5 \mu \mathrm{g}$ of either 1,25-(OH) $)_{2} \mathrm{D}_{3}$ or OCT for $4 \mathrm{~d}$, calcium did not change in the rats receiving vehicle or $\mathrm{OCT}$, but increased from 8.4 to $11.4 \mathrm{mg} / \mathrm{dl}$ in the rats treated with $1,25-(\mathrm{OH})_{2} \mathrm{D}_{3}$. In primary cultures of bovine parathyroid cells, $10 \mathrm{nM}$ OCT was as active as $10 \mathrm{nM} \mathrm{1,25-(OH})_{2} \mathrm{D}_{3}$, suppressing PTH release by 33\%. This suppression is due, at least in part, to blocking of transcription of the PTH gene. Using a probe prepared by random prime labeling of an Msp I fragment of plasmid PTHm122, we found that a single 40-ng dose of OCT or 1,25- $(\mathrm{OH})_{2} \mathrm{D}_{3}$ depressed PTH mRNA levels by $70-80 \%$ by 48 $h$ when compared with vehicle. Thus, OCT is a very effective suppressor of PTH secretion with virtually no calcemic activity. This analogue may be a valuable tool for the treatment of secondary hyperparathyroidism.
\end{abstract}

\section{Introduction}

In recent years the suppressive action of 1,25-dihydroxyvita$\min \mathrm{D}\left(1,25-(\mathrm{OH})_{2} \mathrm{D}_{3}\right)^{1}$ on PTH synthesis and secretion has been well defined. Primary cultures of bovine parathyroid cells have been used to demonstrate that $1,25-(\mathrm{OH})_{2} \mathrm{D}_{3}$ inhibits release of PTH $(1,2)$, decreases the levels of pre-proPTH mRNA (3), and blocks transcription of the PTH gene (4). Silver et al.

Address correspondence to Dr. Alex Brown, Washington University School of Medicine, One Barnes Hospital Plaza, Box 8129, St. Louis, MO 63110. 1989.

Received for publication 8 March 1989 and in revised form 1 May

1. Abbreviations used in this paper: OCT, 22-oxacalcitriol; 1,25- $(\mathrm{OH})_{2} \mathrm{D}_{3}, 1,25$-dihydroxyvitamin $\mathrm{D}$.

J. Clin. Invest.

(C) The American Society for Clinical Investigation, Inc. 0021-9738/89/09/0728/05 $\$ 2.00$

Volume 84, September 1989, 728-732 confirmed this inhibition of transcription in vivo by administration of a dose of $1,25-(\mathrm{OH})_{2} \mathrm{D}_{3}$ that did not raise serum calcium (5). The close correlation between PTH release and the decrease in pre-proPTH mRNA, and the lack of an acute effect of $1,25-(\mathrm{OH})_{2} \mathrm{D}_{3}$ in cell culture suggested that the major action of $1,25-(\mathrm{OH})_{2} \mathrm{D}_{3}$ is at the transcriptional level (1). Furthermore, since physiological concentrations $\left(10^{-11} \mathrm{M}\right)$ of $1,25-(\mathrm{OH})_{2} \mathrm{D}_{3}$ in the culture medium suppressed release and synthesis of PTH, it seems likely that conditions in which $1,25-(\mathrm{OH})_{2} \mathrm{D}_{3}$ levels are abnormally low (e.g., renal failure) would lead to increases in serum PTH.

The suppressive effect of $1,25-(\mathrm{OH})_{2} \mathrm{D}_{3}$ on PTH secretion has lead to the use of this vitamin D metabolite for treatment of secondary hyperparathyroidism. Administration of $1,25-(\mathrm{OH})_{2} \mathrm{D}_{3}$ was found to lower PTH levels in hemodialysis patients more effectively than calcium, even when both substances raised ionized calcium to the same degree (6). These findings are consistent with those of Brown et al., who found that parathyroid cells from patients with secondary hyperparathyroidism are less sensitive to the suppressive effects of calcium (7), and those of Delmez et al., who have recently reported that intravenous $1,25-(\mathrm{OH})_{2} \mathrm{D}_{3}$ treatment of renal failure patients shifts the set point for calcium toward a more normal value (8). Although $1,25-(\mathrm{OH})_{2} \mathrm{D}_{3}$ is now commonly used to treat secondary hyperparathyroidism associated with renal failure, its prolonged use is precluded in some cases by hypercalcemia (9-11).

A number of analogues of $1,25-(\mathrm{OH})_{2} \mathrm{D}_{3}$ have been synthesized that have little calcemic activity but retain the ability to differentiate myeloid leukemia cells. Ostrem et al. reported that 24-homo-1,25-(OH $)_{2} \mathrm{D}_{3}$ could differentiate HL-60 cells but did not increase serum calcium when administered to vitamin D-deficient rats (12). Binderup and Bramm found similar differential activity with $\mathrm{MC} 903$, a $1,25-(\mathrm{OH})_{2} \mathrm{D}_{3}$ analogue with a cyclopropyl group at the end of the side chain (13). Abe et al. showed that 22-oxa-1,25-(OH) $)_{2} \mathrm{D}_{3}(\mathrm{OCT})$, another vitamin $\mathrm{D}$ analogue with very low bone calcium mobilizing activity (14) in vitro, also could differentiate HL-60 cells. Murayama et al. reported that this compound had no calcemic activity in vivo (15). Because a noncalcemic analogue of $1,25-(\mathrm{OH})_{2} \mathrm{D}_{3}$ that could suppress PTH would be useful clinically in treating secondary hyperparathyroidism, we tested OCT for its effectiveness in suppressing PTH secretion in parathyroid cell culture and decreasing pre-proPTH mRNA levels in vivo.

\section{Methods}

Calcemic response to $1,25-(\mathrm{OH})_{2} \mathrm{D}_{3}$ and $\mathrm{OCT}$

The acute calcemic response to OCT and $1,25-(\mathrm{OH})_{2} \mathrm{D}_{3}$ was determined in normal male rats $(250 \mathrm{~g})$ fed a standard chow diet containing 
$1.0 \%$ calcium and $0.4 \%$ phosphorus. At $24 \mathrm{~h}$ after a single intraperitoneal injection of vehicle $(250 \mu \mathrm{l}$ propylene glycol) or $0.2,0.5$, or $1.0 \mu \mathrm{g}$ $\left(0.8,2.0\right.$, or $4.0 \mu \mathrm{g} / \mathrm{kg}$ body weight) of $1,25-(\mathrm{OH})_{2} \mathrm{D}_{3}$ or OCT, blood was taken to measure calcium. The increment in plasma calcium, calculated by subtracting the predose calcium value from the 24-h postdose value for each rat, was determined for each dose of $1,25-(\mathrm{OH})_{2} \mathrm{D}_{3}$ or $\mathrm{OCT}$.

For the chronic studies, normal male rats $(300 \mathrm{~g}$, on the standard chow diet) received daily intraperitoneal injections of vehicle $(250 \mu \mathrm{l}$ propylene glycol) or $0.5 \mu \mathrm{g}(1.7 \mu \mathrm{g} / \mathrm{kg}$ body weight) of either $1,25-(\mathrm{OH})_{2} \mathrm{D}_{3}$ or OCT. After a 5 -h fast each morning the rats were weighed and a blood sample was taken from the tail vein to measure calcium.

\section{PTH secretion in cultured bovine parathyroid cells}

Primary cultures of bovine parathyroid cells were prepared as described by Brown et al. (16) with minor modifications (17). The calcium concentration in the culture media was $1.0 \mathrm{mM}$. After $5 \mathrm{~d}$ in culture the cells were treated with various concentrations of $1,25-(\mathrm{OH})_{2} \mathrm{D}_{3}$ or OCT. Both compounds were aliquotted as ethanol solutions (ethanol alone for controls), dried under nitrogen, and vortexed into the culture media. Cells were incubated with media containing $1,25-(\mathrm{OH})_{2} \mathrm{D}_{3}$ or OCT for $48 \mathrm{~h}$ with a media change after $24 \mathrm{~h}$. To determine the rate of PTH secretion the cells were washed twice and then incubated for $3 \mathrm{~h}$ in fresh media at $37^{\circ} \mathrm{C}$. The media was centrifuged and assayed for PTH by RIA using an antibody (CH9) that recognizes the intact, middle, and $\mathrm{COOH}$-terminal regions of bovine PTH (18). Protein in each sample was determined by sonicating the cells into $1 \mathrm{M} \mathrm{NaOH}$ and assaying an aliquot by the method of Bradford (19). All PTH values were corrected for cell protein.

\section{Determination of pre-proPTH $m R N A$ levels in rat parathyroid glands}

Animals. Normal rats fed a standard chow diet were given a single intraperitoneal injection of vehicle $(250 \mu \mathrm{l}$ propylene glycol) or 100 pmol $(0.13 \mu \mathrm{g} / \mathrm{kg}$ body weight $)$ of either $1,25-(\mathrm{OH})_{2} \mathrm{D}_{3}$ or OCT. After $48 \mathrm{~h}$ the rats were anesthetized with chloral hydrate, blood was taken from the aorta, and the parathyroid glands were removed and placed immediately in liquid nitrogen.

Preparation of radioactive probes. An 800-bp Msp I fragment of plasmid PTHm 122 kindly provided by Dr. H. Kronenberg (Harvard Medical School) was labeled to a sp act of $\sim 10^{9} \mathrm{cpm} / \mu \mathrm{g}$ using a random-primed kit from Boehringer Mannheim Biochemicals (Indianapolis, IN). A synthetic oligonucleotide probe to rat cytoplasmic $\beta$-actin (Clontech, Palo Alto, CA) was labeled to a sp act of $\sim 10^{7}$ $\mathrm{cpm} / \mu \mathrm{g}$ by a $5^{\prime}$ end-labeling kit using T4 kinase (IBI, New Haven, CT).

Determination of pre-proPTH $m R N A$ levels. Extracts of cytoplasmic RNA were prepared from a pool of 16 rat parathyroid glands. The previously frozen glands were homogenized in $45 \mu \mathrm{l}$ of $10 \mathrm{mM}$ Tris$\mathrm{HCl}, 1 \mathrm{mM}$ EDTA, pH 8 , and $5 \mu \mathrm{l}$ of $5 \% \mathrm{NP}-40$ was added. After $5 \mathrm{~min}$ on ice the homogenate was centrifuged in a microfuge at $4^{\circ} \mathrm{C}$ for 5 min. The supernatant was removed and mixed with $30 \mu \mathrm{l}$ of $20 \times$ standard saline citrate (SSC; $1 \times$ SCC is $0.15 \mathrm{M}$ sodium chloride, 0.01 $\mathrm{M}$ sodium citrate, $\mathrm{pH} 7$ ) and $20 \mu \mathrm{l}$ of $37 \%$ formaldehyde, and incubated at $60^{\circ} \mathrm{C}$ for $15 \mathrm{~min}$. Dilutions of the extracts were applied to nitrocellulose in a slot blot apparatus (Bio-Rad Laboratories, Richmond, $\mathrm{CA}$ ), and the filter baked at $80^{\circ} \mathrm{C}$ for $2 \mathrm{~h}$ under vacuum. The filters were prehybridized in $5 \times$ SSC, $5 \times$ Denhardt's, and $100 \mu \mathrm{g} / \mathrm{ml}$ salmon testes DNA in $50 \%$ formamide at $42^{\circ} \mathrm{C}$ for $3 \mathrm{~h}$. The filters were then placed in the appropriate hybridization solution of $5 \times$ SSC, $1 \times$ Denhardt's, $100 \mu \mathrm{g} / \mathrm{ml}$ salmon testes DNA, and $10 \%$ dextran sulfate in $50 \%$ formamide containing $10^{6} \mathrm{cpm} / \mathrm{ml}$ of either the PTHm 122 probe or the $\beta$-actin oligonucleotide probe. The hybridization was carried out overnight at the less stringent room temperature since there are differences in the DNA sequence between the human PTH cDNA probe and the rat pre-proPTH mRNA. The filters were washed the next day at room temperature once in $4 \times$ SSC, $0.1 \%$ SDS and three times in $1 \times$ SSC, $0.1 \%$ SDS before drying and subsequent autoradiography. Again, this is a less stringent wash so as not to obliterate the species difference between the cDNA probe and the desired measurement of mRNA. As a control, cytoplasmic RNA extracts from $10 \mathrm{mg}$ of rat liver, prepared as described above, were assayed in an identical manner.

Northern blot analysis. A portion of the cytoplasmic RNA pool extracted from the rat parathyroid glands was treated with phenol and ethanol was precipitated with carrier tRNA and subjected to electrophoresis on a $1.2 \%$ agarose gel containing formaldehyde. The RNA was transferred to nitrocellulose by capillary action, and the nitrocellulose was baked, prehybridized, and hybridized as described above. The migration of ribosomal RNA was determined by ethidium bromide staining of an adjacent lane in the agarose gel containing a liver RNA extract.

\section{Results}

Calcemic response to 1,25-(OH $)_{2} D_{3}$ and $O C T$. The calcemic activity of OCT was examined in normal rats and compared with that for $1,25-(\mathrm{OH})_{2} \mathrm{D}_{3}$. Rats received a single intraperitoneal injection of vehicle ( $250 \mu$ l propylene glycol) or various doses of either $1,25-(\mathrm{OH})_{2} \mathrm{D}_{3}$ or $\mathrm{OCT}$, and plasma calcium was measured $24 \mathrm{~h}$ later. As shown in Fig. 1, doses of OCT up to 1 $\mu \mathrm{g}(4 \mu \mathrm{g} / \mathrm{kg}$ body weight) did not increase plasma calcium, whereas $1,25-(\mathrm{OH})_{2} \mathrm{D}_{3}$, as expected, raised plasma calcium in a dose-dependent manner with an increment of $1.4 \mathrm{mg} / \mathrm{dl}$ at the $1-\mu \mathrm{g}$ dose.

To evaluate more chronic administration, normal rats received vehicle or $0.5 \mu \mathrm{g}(1.7 \mu \mathrm{g} / \mathrm{kg}$ body weight $)$ of $1,25-(\mathrm{OH})_{2} \mathrm{D}_{3}$ or OCT daily for $4 \mathrm{~d}$. Fig. 2 shows that even with prolonged treatment with OCT, plasma calcium did not increase. In contrast, rats receiving a comparable dose of $1,25-(\mathrm{OH})_{2} \mathrm{D}_{3}$ became very hypercalcemic, and by $4 \mathrm{~d}$ calcium had increased by $3 \mathrm{mg} / \mathrm{dl}$. Thus, it is clear that OCT has little if any calcemic activity in vivo as reported previously (15).

PTH secretion by cultured bovine parathyroid cells. OCT was initially tested for its ability to suppress PTH release from primary cultures of bovine parathyroid cells. We and others have shown previously that $1,25-(\mathrm{OH})_{2} \mathrm{D}_{3}$ suppresses $\mathrm{PTH}$ secretion, and that prolonged exposure ( $>24 \mathrm{~h}$ ) to the hormone is required to observe this effect $(1,2)$. Therefore, we incubated the parathyroid cultures for $48 \mathrm{~h}$ with various doses of OCT and compared the suppression with that obtained with $1,25-(\mathrm{OH})_{2} \mathrm{D}_{3}$. Fig. 3 shows a dose-response curve for suppression of PTH by OCT and $1,25-(\mathrm{OH})_{2} \mathrm{D}_{3}$. Both compounds

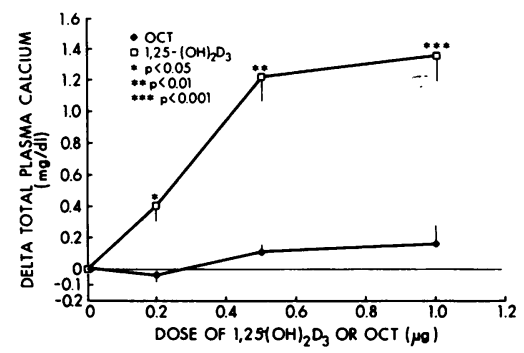

Figure 1. Calcemic response to various doses of OCT and $1,25-(\mathrm{OH})_{2} \mathrm{D}_{3}$. Male Sprague-Dawley rats, $250 \mathrm{~g}$, were given a single intraperitoneal injection of vehicle or the specified dose of OCT or $1,25-(\mathrm{OH})_{2} \mathrm{D}_{3}$. The change in serum calcium values were calculated as described in Methods. All values are expressed as mean \pm SEM, $n=4$. Statistical differences at each dose were determined by $t$ test. The $P$ values shown are for the differences between control vs. $1,25-(\mathrm{OH})_{2} \mathrm{D}_{3}$-treated rats. The same statistical differences were observed for $\mathrm{OCT}$ vs. $1,25-(\mathrm{OH})_{2} \mathrm{D}_{3}$-treated rats. OCT-treated rats did not differ significantly from control rats. 


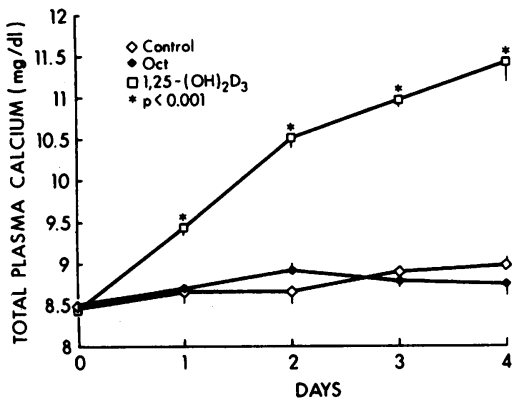

Figure 2. Calcemic response to chronic administration of OCT and $1,25-(\mathrm{OH})_{2} \mathrm{D}_{3}$. Male rats $(300 \mathrm{~g})$ were given daily intraperitoneal injections of vehicle or $0.5 \mu \mathrm{g}$ of either OCT or $1,25-(\mathrm{OH})_{2} \mathrm{D}_{3}$ for $4 \mathrm{~d}$. After a 5 -h fast each morning, blood was drawn and the next injection given. All

values are expressed as mean \pm SEM, $n=6$. Statistical differences at each time point were determined by $t$ test. $P<0.001$ was observed at each time for both control vs. $1,25-(\mathrm{OH})_{2} \mathrm{D}_{3}$-treated rats and $\mathrm{OCT}$ vs. $1,25-(\mathrm{OH})_{2} \mathrm{D}_{3}$-treated rats. No significant differences were observed between control and OCT-treated rats at any time point.

suppressed the release of PTH in a dose-dependent fashion. In three independent experiments PTH was reduced by $30-35 \%$ by both $1,25-(\mathrm{OH})_{2} \mathrm{D}_{3}$ and OCT at $10^{-8} \mathrm{M}(P<0.05)$. Although OCT appeared to be slightly more inhibitory at intermediate concentrations, the difference was not statistically significant.

Suppression of pre-proPTH mRNA levels in vivo. The suppressive activity of OCT on the parathyroid glands was tested in vivo. It is well established that $1,25-(\mathrm{OH})_{2} \mathrm{D}_{3}$ inhibits the transcription of the PTH gene in vivo (5), and that the decrease in pre-proPTH mRNA accounts, at least in part, for the suppression of PTH release by parathyroid cells. Therefore, we measured the levels of pre-proPTH mRNA in rat parathyroid glands $48 \mathrm{~h}$ after treatment with vehicle or $40 \mathrm{ng}(0.13 \mu \mathrm{g} / \mathrm{kg}$ body weight) of either OCT or $1,25-(\mathrm{OH})_{2} \mathrm{D}_{3}$. This low dose was necessary since higher amounts of $1,25-(\mathrm{OH})_{2} \mathrm{D}_{3}$ will raise serum calcium, which can also decrease the levels of preproPTH mRNA (20). In this experiment pre- and posttreatment calcium values were $8.66 \pm 0.07$ and $8.67 \pm 0.10 \mathrm{mg} / \mathrm{dl}$ in the $1,25-(\mathrm{OH})_{2} \mathrm{D}_{3}$-treated rats and $8.51 \pm 0.10$ vs. $8.48 \pm 0.09$ for the OCT-treated rats.

Pre-proPTH mRNA could be detected reproducibly by slot blot analysis of the cytoplasmic RNA extract from as little as one-fourth of a normal rat parathyroid gland (Fig. 4, left). No hybridizable RNA was detected in cytoplasmic mRNA extracts from rat liver (Fig. 4). Treatment with either $1,25-(\mathrm{OH})_{2} \mathrm{D}_{3}$ or OCT caused a marked reduction in the hybridizable PTH mRNA per parathyroid gland (Fig. 4). As seen in Fig. 4 (right), the amounts of $\beta$-actin mRNA were the same

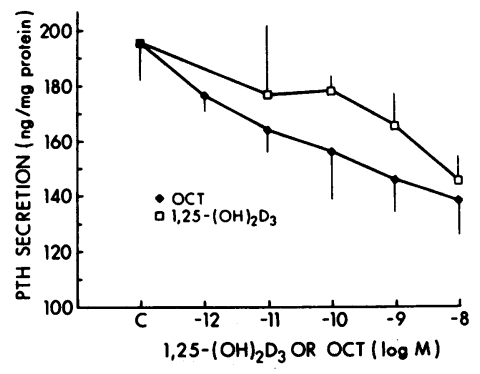

Figure 3. Effects of OCT and $1,25-(\mathrm{OH})_{2} \mathrm{D}_{3}$ on PTH secretion from primary cultures of bovine parathyroid cells. Cells were treated for $48 \mathrm{~h}$ with the specified concentrations of OCT or $1,25-(\mathrm{OH})_{2} \mathrm{D}_{3}$. The cells were then washed and media was replaced for a 3-h incubation to measure PTH release. The media

samples were centrifuged and assayed for PTH by RIA. All values are corrected for cell protein and expressed as mean \pm SEM, $n=4$.

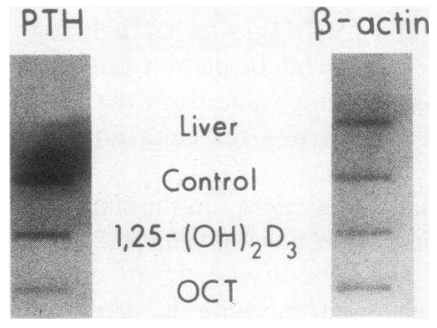

Figure 4. Slot blot analysis of cytoplasmic RNA extracted from liver, and from parathyroid glands from control, $1,25-(\mathrm{OH})_{2} \mathrm{D}_{3}$-treated, and OCT-treated rats. Slots on the left were hybridized with PTHm122 cDNA, while slots on the right were hybridized with a rat $\beta$-actin oligonucleotide cDNA.

in the parathyroid gland extracts from all three groups, indicating that equivalent amounts of RNA were applied to each slot. The higher amount of hybridization of the $\beta$-actin probe to the liver mRNA is due to heavier loading of this sample. On the average there was a $70 \%$ reduction in the hybridizable pre-proPTH mRNA by treatment with either OCT or $1,25-(\mathrm{OH})_{2} \mathrm{D}_{3}$ compared with control. Northern blot analysis of the RNA extracts revealed that the bulk of the hybridizable pre-proPTH mRNA species have a size of $\sim 850$ bases (Fig. 5 , arrow), using ribosomal RNA at 4,780 and 1,870 bases as standard, which is consistent with the estimates of the rat PTH message. There appears to be a small amount of degradation of the mRNA during preparation as evidenced by the hybrid signal $\sim 300$ bases in size. Again there is more hybridizable mRNA present in the extracts of normal glands compared with the extracts obtained from rats treated with $1,25-(\mathrm{OH})_{2} \mathrm{D}_{3}$ or OCT.

\section{Discussion}

The ability of $1,25-(\mathrm{OH})_{2} \mathrm{D}_{3}$ to feed back on the parathyroid glands to suppress PTH is well established. The parathyroid glands were shown to be target tissues for $1,25-(\mathrm{OH})_{2} \mathrm{D}_{3}$ by Henry and Norman by in vivo labeling of this tissue with tritiated ligand (21). Subsequent studies by Brumbaugh,

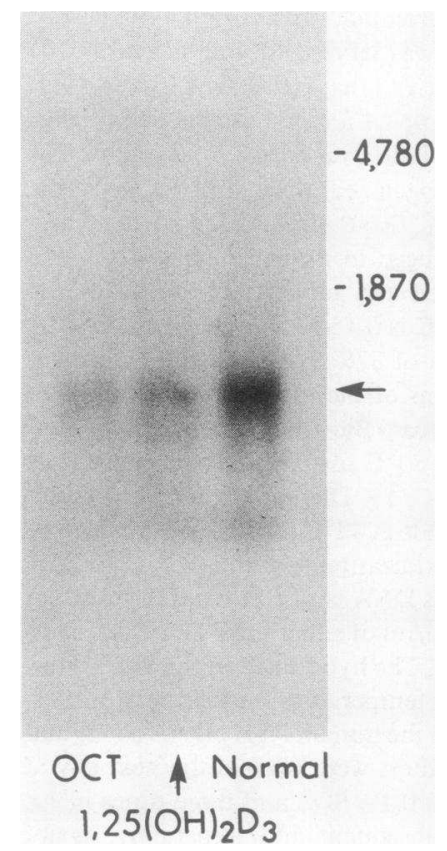

Figure 5. Northern blot analysis of cytoplasmic RNA extracted from the parathyroid glands of normal, $1,25-(\mathrm{OH})_{2} \mathrm{D}_{3}$-treated, and OCT-treated rats. The blot was hybridized with PTHm 122 cDNA. 
Hughes, and Haussler demonstrated the presence of the cellular receptor for $1,25-(\mathrm{OH})_{2} \mathrm{D}_{3}$ in extracts from parathyroid glands (22). That $1,25-(\mathrm{OH})_{2} \mathrm{D}_{3}$ can suppress PTH directly, independent of calcium, was first shown in vivo by Chertow et al. (23). Experiments in cell culture confirmed this direct effect of $1,25-(\mathrm{OH})_{2} \mathrm{D}_{3}$ on PTH secretion $(1,2)$. This suppression required $>24 \mathrm{~h}$ to be evident, and the activity of various vitamin $\mathrm{D}$ metabolites correlated with their affinity for the $1,25-(\mathrm{OH})_{2} \mathrm{D}_{3}$ receptor, suggesting a nuclear-mediated mechanism for $1,25-(\mathrm{OH})_{2} \mathrm{D}_{3}$. Silver et al. observed a decrease in pre-proPTH mRNA levels in cultured bovine parathyroid cells by $24-48 \mathrm{~h}$ of treatment with $1,25-(\mathrm{OH})_{2} \mathrm{D}_{3}$ (3). Using a nuclear runoff technique, a significant decrease in transcription of the PTH gene was observed by $6 \mathrm{~h}$ in cell culture (4) and as early as $3 \mathrm{~h}$ in rats after intraperitoneal injection of $1,25-(\mathrm{OH})_{2} \mathrm{D}_{3}(5)$.

The suppressive activity of $1,25-(\mathrm{OH})_{2} \mathrm{D}_{3}$ on PTH has been used clinically for the treatment of secondary hyperparathyroidism (6), but in some cases prolonged administration can lead to hypercalcemia $(9-11)$. For this reason we tested the noncalcemic 22-oxa analogue of $1,25-(\mathrm{OH})_{2} \mathrm{D}_{3}$ for its activity in suppressing PTH. We found that this analogue (OCT) was capable of suppressing PTH release from cultured parathyroid cells in a dose-dependent manner. In fact, it appeared to be slightly, but not significantly, more active than the parent compound. The affinity of OCT for the chick intestinal receptor was reported to be 14 times less than that for $1,25-(\mathrm{OH})_{2} \mathrm{D}_{3}$ (15), but the relative binding affinities of these two compounds for the $1,25-(\mathrm{OH})_{2} \mathrm{D}_{3}$ receptor in parathyroid cells are not yet known.

We also showed that OCT is active in vivo and, like $1,25-(\mathrm{OH})_{2} \mathrm{D}_{3}$, decreases pre-proPTH mRNA levels. Thus, the lack of calcemic activity is not the result of rapid metabolism or clearance of OCT. Abe and co-workers have also demonstrated activity of OCT on modulation of the immune response in vivo (24). The problem of hypercalcemia with large doses of $1,25-(\mathrm{OH})_{2} \mathrm{D}_{3}$ has spurred the development of vitamin $\mathrm{D}$ analogues that retain the desired activity with little, if any, calcemic activity. A number of analogues of $1,25-(\mathrm{OH})_{2} \mathrm{D}_{3}$ have recently been developed that retain the cell-differentiating activity of the parent hormone with very low, if any, calcemic activity. Ostrem and co-workers reported that homo analogues of $1,25-(\mathrm{OH})_{2} \mathrm{D}_{3}$ with extra carbons in their side chains can differentiate the human myeloid leukemia cell line, HL-60, to a monocytic cell type, with much lower calcemic activity than $1,25-(\mathrm{OH})_{2} \mathrm{D}_{3}(12)$. Similarly, an analogue of $1,25-(\mathrm{OH})_{2} \mathrm{D}_{3}, \mathrm{MC} 903$, with a cyclopropyl group at the end of the side chain was shown to differentiate U937 cells with very little calcemic activity (13). The latter has been shown to be very effective in treating psoriasis. The analogue used in the present study, OCT, was previously found to retain the activity of the parent compound to differentiate HL-60 cells with little calcium mobilizing activity in vitro (14) or in vivo (15). The ability of OCT to suppress PTH synthesis and secretion is another example of the selective activities of these vitamin $\mathrm{D}$ analogues. The mechanism of this selectivity is not known. The mechanism currently accepted for $1,25-(\mathrm{OH})_{2} \mathrm{D}_{3}$ receptor action assumes that receptors are identical in all cell types and thus the intestine and bone would be expected to respond to OCT as the parathyroid glands do. Therefore, other factors such as tissue-specific uptake or metabolism may be responsible for the selective activity of OCT. These vitamin D analogues will be valuable tools for defining further the role of the ligand structure in determining the target gene specificity of the receptor complex.

From the clinical point of view OCT may be a valuable agent for the treatment of secondary hyperparathyroidism. Control of serum phosphorus is mandatory before vitamin D is administered to uremic patients. Since phosphate binders containing aluminum frequently induce aluminum accumulation, with its well-known deleterious effects calcium carbonate is currently the phosphate binder of choice (25-28). Unfortunately, the simultaneous administration of large doses of calcium carbonate and $1,25-(\mathrm{OH})_{2} \mathrm{D}_{3}$ frequently induces severe hypercalcemia precluding the administration of therapeutic doses of $1,25-(\mathrm{OH})_{2} \mathrm{D}_{3}$. Thus, the use of an analogue of vitamin $\mathrm{D}$ without a calcemic effect but with the same action on parathyroid synthesis and release as $1,25-(\mathrm{OH})_{2} \mathrm{D}_{3}$, may provide a unique therapeutic tool in the treatment of secondary hyperparathyroidism in patients with chronic renal failure.

\section{Acknowledgments}

The authors wish to express their appreciation to Mrs. Patricia Shy for her assistance in the preparation of the manuscript.

\section{References}

1. Cantley, L. K., J. Russel, D. Lettieri, and L. M. Sherwood. 1985. 1,25-Dihydroxyvitamin $D_{3}$ suppresses PTH secretion from bovine parathyroid cells in tissue culture. Endocrinology. 117:2114-2119.

2. Chan, Y.-L., C. McKay, E. Dye, and E. Slatopolsky. 1986. The effect of 1,25-dihydroxycholecalciferol on parathyroid hormone secretion by monolayer cultures of bovine parathyroid cells. Calcif. Tissue Int. 38:27-32.

3. Silver, J., J. Russell, and L. M. Sherwood. 1985. Regulation by vitamin D metabolites of messenger RNA for pre-proparathyroid hormone in isolated bovine parathyroid cells. Proc. Natl. Acad. Sci. USA. 82:4270-4273.

4. Russell, J., D. Lettieri, and L. M. Sherwood. 1986. Suppression by $1,25-(\mathrm{OH})_{2} \mathrm{D}_{3}$ of transcription of the parathyroid hormone gene. Endocrinology. 119:2864-2866.

5. Silver, J., T. Naveh-Many, H. Mayer, H. J. Schmeizer, and M. M. Popovtzer. 1986. Regulation by vitamin D metabolites of parathyroid hormone gene transcription in vivo in the rat. J. Clin. Invest. 78:1296-1301.

6. Slatopolsky, E., C. Weerts, J. Thielan, R. Horst, H. Harter, and K. J. Martin. 1984. Marked suppression of secondary hyperparathyroidism by intravenous administration of 1,25-dihydroxycholecalciferol in uremic patients. J. Clin. Invest. 74:2136-2143.

7. Brown, E. M., R. E. Wilson, R. C. Eastman, J. Pallota, and S. P. Marynick. 1982. Abnormal regulation of parathyroid hormone release by calcium in secondary hyperparathyroidism due to chronic renal failure. J. Clin. Endocrinol. Metab. 54:172-179.

8. Delmez, J., C. Tindira, P. Grooms, A. Dusso, D. W. Windus, and E. Slatopolsky. 1989. Parathyroid hormone suppression by intravenous $1,25-(\mathrm{OH})_{2} \mathrm{D}$. A role for increased sensitivity to calcium. $J$. Clin. Invest. 83:1349-1355.

9. Berl, T., A. S. Berns, W. E. Huffer, K. Hammill, A. C. Alfrey, C. D. Arnaud, and R. W. Shrier. 1978. 1,25-Dihydroxycholecalciferol effects in chronic dialysis: a double-blind controlled study. Ann. Intern. Med. 88:774-780.

10. Prior, J. C., E. C. Cameron, H. S. Ballon, D. S. Lirenman, M. V. Moriarity, and J. D. E. Price. 1979. Experience with 1,25-dihydroxycholecalciferol therapy in undergoing hemodialysis patients with progressive vitamin $\mathrm{D}_{2}$-treated osteodystrophy. Am. J. Med. 67:583-589.

11. Salusky, I. B., R. S. Fine, H. Kangarloo, R. Gold, L. Paunier, 
W. G. Goodman, J. E. Brill, G. Gilli, E. Slatopolsky, and J. W. Coburn. 1987. "High-dose" calcitriol for control of renal osteodystrophy in children on CAPD. Kidney Int. 32:89-95.

12. Ostrem, V. K., Y. Tanaka, J. Prahl, H. F. DeLuca, and N. Ikekawa. 1987. 24- and 26-homo-1,25-dihydroxyvitamin $\mathrm{D}_{3}$ : preferential activity in inducing differentiation of human leukemia cells HL-60 in vitro. Proc. Natl. Acad. Sci. USA. 84:2610-2614.

13. Binderup, L., and E. Bramm. 1988. Effects of a novel vitamin D analogue MC903 on cell proliferation and differentiation in vitro and on calcium metabolism in vivo. Biochem. Pharmacol. 37:889-895.

14. Abe, J., M. Morikawa, K. Miyamoto, S.-I. Kaiho, M. Fukushima, C. Miyaura, E. Abe, T. Suda, and Y. Nishii. 1987. Synthetic analogues of vitamin $\mathrm{D}_{3}$ with an oxygen atom in the side chain. FEBS (Fed. Eur. Biochem. Soc.) Lett. 226:58-62.

15. Murayama, E., K. Miyamoto, N. Kubodera, T. Mori, and I. Matsunaga. 1987. Synthetic studies of vitamin $D_{3}$ analogues. VIII. Synthesis of 22-oxavitamin $\mathrm{D}_{3}$ analogues. Chem. Pharm. Bull. (Tokyo). 34:4410-4413.

16. Brown, E. M., S. Hurwitz, and G. D. Aurback. 1976. Preparation of viable bovine parathyroid cells. Endocrinology. 99:1582-1588.

17. Morrissey, J. J., and D. V. Cohn. 1978. The effect of calcium and magnesium on the secretion of parathormone and parathyroid secretory protein by isolated porcine parathyroid cells. Endocrinology. 103:2081-2090.

18. Hruska, K. A., R. Kopelman, W. E. Rutherford, S. Klahr, and E. Slatopolsky. 1975. Metabolism of immunoreactive parathyroid hormone in the dog. The role of the kidney and effects of chronic renal disease. J. Clin. Invest. 56:39-48.

19. Bradford, M. M. 1976. A rapid and sensitive method for the quantitation of microgram quantities of protein utilizing the principle of protein-dye binding. Anal. Biochem. 72:248-254.

20. Russell, J. R., D. Lettieri, and L. M. Sherwood. 1983. Direct regulation by calcium of cytoplasmic mRNA coding for pre-proparathyroid hormone in isolated bovine parathyroid cells. J. Clin. Invest. 72:1851-1855.
21. Henry, H. L., and A. W. Norman. 1975. Studies on the mechanism of action of calciferol. VII. Localization of 1,25-dihydroxy vitamin $\mathrm{D}_{3}$ in chick parathyroid glands. Biochem. Biophys. Res. Commun. 62:781-788.

22. Brumbaugh, P. F., M. R. Hughes, and M. R. Haussler. Cytoplasmic and nuclear binding components for 1,25-dihydroxyvitamin $\mathrm{D}_{3}$ in chick parathyroid glands. Proc. Natl. Acad. Sci. USA. 72:48714875.

23. Chertow, B. S., J. E. Baylink, J. E. Wegedal, M. H. H. Su, and A. W. Norman. 1975. Decrease in serum immunoreactive parathyroid hormone in rats and in parathyroid hormone secretion in vitro by 1,25-dihydroxycholecalciferol. J. Clin. Invest. 56:668-678.

24. Abe, J., M. Morikawa, Y. Takita, K. Miyamoto, S. Kaiho, C. Miyaura, E. Abe, T. Suda, and Y. Nishii. 1988. 1,25-Dihydroxy-22oxavitamin $\mathrm{D}_{3}$ : A New Synthetic Analogue of Vitamin $\mathrm{D}_{3}$ Having Potent Differentiation-inducing Activity Without Inducing Hypercalcemia in vivo and in vitro. Seventh Workshop on Vitamin D, Rancho Mirage, CA. 60. (Abstr.)

25. Moriniere, P., A. Roussel, Y. Tahiri, J. F. Fremont, G. Maurel, M. C. Jaudon, J. Gueris, and A. Fournier. 1983. Substitution of aluminum hydroxide by high doses of calcium carbonate in patients on chronic hemodialysis: disappearance of hyperaluminaemia and equal control of hyperparathyroidism. Proc. Eur. Dial. Transplant Assoc. 19:784-787.

26. Salusky, I. B., J. W. Coburn, J. Foley, P. Nelson, and R. N. Fine. 1986. Calcium carbonate as a phosphate binder in children on dialysis: effect on plasma aluminum levels. J. Pediatr. 108:767-771.

27. Slatopolsky, E., C. Weerts, S. Lopez-Hilker, K. Norwood, M. Zink, D. Windus, and J. Delmez. 1986. Calcium carbonate as a phosphate binder in patients with chronic renal failure undergoing dialysis. N. Engl. J. Med. 315:157-161.

28. Hercz, G., J. A. Kraut, D. A. Andress, N. Howard, C. Roberts, J. H. Shinaberger, D. J. Sherrard, and J. W. Coburn. 1986. Use of calcium carbonate as a phosphate binder in dialysis patients. Miner. Electrolyte Metab. 12:314-319. 